UDK 811.163.42’367

Izvorni znanstveni rad

Rukopis primljen 4. III. 2021.

Prihvaćen za tisak 21. V. 2021.

doi.org/10.31724/rihjj.47.2.1

\title{
Matea Birtić
}

Institute of Croatian Language and Linguistics Ulica Republike Austrije 16, HR-10000 Zagreb orcid.org/0000-0001-5927-782X

mbirtic@ihjj.hr

\section{Ivana Brač}

Institute of Croatian Language and Linguistics Ulica Republike Austrije 16, HR-10000 Zagreb orcid.org/0000-0002-3660-5285

ibrac@ihjj.hr

\section{BASIC CHARACTERISTICS AND ASPECTUAL PROPERTIES OF CROATIAN ObjExp VERBS}

This paper ${ }^{1}$ discusses the basic characteristics of ObjExp verbs in Croatian (thematic roles, argument structure, anticausative variant, aspect of the verb), with special attention paid to the aspectual properties of such verbs. According to various authors (Arad 1998, Pylkkänen 2000, Biały 2005, Grafmiller 2013), ObjExp verbs are not a unified aspectual class since they can be interpreted as both stative and non-stative verbs. Five diagnostics that differentiate between stative and non-stative interpretation are applied to a sample of 40 verbs: (1) passive formation; (2) use in the punctual past tense; (3) co-occurrence with agent-oriented adverbs; (4) use of a verb in the imperative mood; and (5) the ability of the verb to be used as a complement of control verbs (Grafmiller 2013). The results of this research show that all Croatian ObjExp verbs with primary psychological meaning have an anticausative variant derived by reflexive morphology, that most verbs have two (or three) interpretations, and that perfective ObjExp verbs can probably be more easily interpreted as non-stative than imperfective ones.

This work has been fully supported by Croatian Science Foundation under the project Syntactic and Semantic Analysis of Arguments and Adjuncts in Croatian - SARGADA (2019-04-7896). 


\section{Introduction}

In the last few decades, much attention has been paid to psychological predicates (e.g. Belletti and Rizzi 1988, Grimshaw 1990, Croft 1993, Pesetsky 1995, Arad 1998, Biały 2005, Landau 2010, Grafmiller 2013, Alexiadou and Iordăchioaia 2014, Rozwadowska 2017). As has been frequently recorded in many languages, experiencers could be realized either as subjects or objects within psychological predicates. Accordingly, the two classes of psychological predicates are called Subject Experiencer Verbs (SubjExp Verbs) or Object Experiencer Verbs (ObjExp Verbs), but sometimes are also named after their characteristic exponents in English or Italian, namely the fear or temere class (SubjExpVerbs) and the frighten or preoccupare class (ObjExpVerbs) ${ }^{2}$ (Belletti and Rizzi 1988, Grimshaw 1990, Landau 2010). Belletti and Rizzi (1988) add a third class of verbs whose experiencer is realized inside a prepositional phrase or as a nominal in the dative case (Dative Experiencer Verbs, the appeal to or piacere class). This pattern, observed in many languages, is attested in Croatian too (Šaravanja 2011, Brač and Matas Ivanković 2018, Birtić and Runjaić 2019). In Croatian, the experiencer is expressed as a nominative subject (1), accusative object (2), and dative object/argument (3):

$\begin{array}{llll}\text { Ivan } & \text { se } & \text { boji } & \text { pasa. } \\ \text { Ivan.nom. } & \text { se.refl. } & \text { fear.3.sg.pres. } & \text { dogs.gen.pl. } \\ \text { 'Ivan fears dogs.' } & & & \end{array}$

(2)

Psi plaše Ivana.

dogs.nom.pl. frighten.3.pl.pres. Ivan.acc.

'Dogs frighten Ivan.'
Ivanu
se $\quad$ sviđa
taj
pas.
Ivan.dat.
se.refl. likes.3.sg.pres.
this.nom.sg.
dog.nom.sg.
'Ivan likes this dog.'

This paper focuses on ObjExp verbs, as illustrated in the example (2). In Croatian sentences like this, an experiencer (the person who feels or experiences some emotion) is realized as a nominal phrase marked with the accusative case, while

\footnotetext{
2 Abbreviations used in this paper: acc. - accusative, adj. - adjective, biasp. - biaspectual, dat. - dative, fem. - feminine, gen. - genitive, imp. - imperative, impf. - imperfective, inf. - infinitive, inst. - instrumental, loc. - locative, masc. - masculine, neu. - neuter, nom. - nominative, ObjExp - object experiencer, part. participle, pass. - passive, past. - past, perf. - perfective, pl. - plural, pres. - present, refl. - reflexive, sg. - singular, SubjExp - subject experiencer.
} 
the other argument (non-experiencer), which causes or stimulates an emotion or reaction in the experiencer, is realized as a nominal with a nominative case. There are different proposals in linguistic literature about the nature and proper labelling of the non-experiencer argument in sentences with ObjExp verbs. According to Belletti and Rizzi (1998), the sentences in (1), (2), and (3) have arguments with the same thematic roles but with different case markings. In all sentences, psi 'dogs' is the theme argument and Ivan is the experiencer, but their morphological marking differs. In accordance with the theoretical inventory of that time, sentences (1) and (2) are supposed to have the same D-structure, with the theme assigned to an argument inside the VP, but in sentence (2) the theme argument has moved from the position internal to the verb phrase to the subject position to receive the nominative case. Croft (1993) labels the nominal psi 'dogs' as a stimulus, and Ivan as an experiencer. According to Pesetsky (1995), sentences with SubjExp and ObjExp verbs do not have the same arguments with the same thematic roles. Ivan is the experiencer both in sentence (1) and (2), while psi 'dogs' is the target or subject matter of emotion in sentence (1) and cause in the sentence (2). In accordance with the thematic hierarchy, with ObjExp verbs the cause is higher than the experiencer, which in turn is higher than the target or subject matter of emotion. The result is that the cause is in the position of Spec VP with ObjExp verbs, while with SubjExp verbs the experiencer is in that position.

The behaviour of Object Experiencer Verbs is one of the most researched topics within the semantic class of psychological verbs. On the one hand, these verbs pose a problem for theories of linking since they realize an argument with the same thematic role (experiencer) in two or even three syntactic ways (or syntactic positions). On the other hand, it has been recorded that ObjExp verbs are not a uniform aspectual class. They can be both eventive and stative (Pylkkänen 2000). Arad (1998) distinguishes three distinct readings of these verbs: agentive, eventive, and stative. Biały (2005) pointed out that there are stative and non-stative ObjExp verbs in Polish, the former having two arguments (experiencer, target/subject matter), while the latter can potentially take three arguments (cause, experiencer, target/subject matter).

The aim of the research presented in this paper is to discover and describe some special characteristics of Croatian ObjExp verbs and to see if these verbs can 
be divided into aspectual subclasses too. With respect to aspectual classes, the focus will mainly be on the separation of stative from non-stative (eventive) verbs using some well-known diagnostics, setting aside the tripartite division of ObjExp verbs for now (stative, eventive, agentive).

A list was compiled of 140 psychological ObjExp verbs from different sources (Croatian grammar books, dictionaries, and verbs that spontaneously came to mind). However, after 1) verifying the use of each verb with the accusative experiencer in corpora, 2) determining if the ObjExp verb is primarily psychological or not, 3 ) checking if the reflexive variant of the corresponding verb is possible, and 4) determining its aspect, only 40 verbs were thoroughly examined with respect to their stativity/non-stativity by well-known diagnostics.

This paper is organized as follows. This Section (1) serves as an introduction. The argument structure of Croatian ObjExp verbs and their possible anticausative/reflexive correlates, the division of psychological verbs into primary and non-primary psychological classes, and the aspect of the verbs are presented in the Section 2. Section 3 describes the differentiation between the aspectual subclasses of ObjExp verbs, while subsections 3.1, 3.2, 3.3, 3.4, and 3.5 give five diagnostics (whether passive formation is possible, the ability of the verb to be in the punctual past tense, whether the verb can be accompanied by agent-oriented adverbs, the use of the verb in the imperative mood, and the ability of the verb to be a complement of a control verb) for this differentiation. Finally, Section 4 is the conclusion.

\section{The argument structure, anticausative (reflexive) correlates, the primary semantic class, and the aspect of ObjExp verbs}

Croatian ObjExp verbs show a fixed pattern with an experiencer realized as an accusative object and a cause/stimulus as a nominative subject (example in 2). With some ObjExp verbs, there is a third NP in the instrumental case (4.a and b):
(4) a. On
me
zabrinuo
svojim
postupcima.
he.nom.sg. me.acc.sg.
worried.past.part.masc.sg
his.refl.inst.pl. actions.inst.pl.
'He worried me with his actions.' 
b. Domaćin nas je iznenadio večerom. host.nom.sg. us.acc.pl. is.3.sg. surprised.past.part.masc.sg. dinner.inst.sg. 'The host surprised us with dinner.'

The same phenomenon is recorded for Polish ObjExp verbs in Biały (2005). According to Biały (2005), with stative ObjExp verbs a third instrumental NP must be coreferential with the subject. The instrumental NP in such cases is considered one characteristic of a subject NP, hence not the third argument (see also Brač 2018). This fact is supported by the coexistence of both nouns in the same phrase. Bialy's observation is confirmed by Croatian data below (5):
(5) Njegovi
postupci
$\mathrm{su} \quad \mathrm{me}$
zabrinuli.
his.sg.nom.
'His actions worried me.'
actions.nom.sg. are.3.pl. me.acc.sg.
worried.past.part.masc.pl.

With non-stative ObjExp verbs, the instrumental NP is a 'true' third argument, and need not be coreferential with the subject (see the example in $4 b$ ).

Almost all Croatian ObjExp verbs have a corresponding anticausative (reflexive) variant in which the same verb is accompanied by the reflexive marker se, and the experiencer in the object position appears as the subject in the nominative case (7). The existence of an anticausative variant of an ObjExp verb derived by reflexive morphology is recorded for several languages (e.g. Dutch, Italian, Hebrew), including Polish (Biały 2005: 70). Although psychological verbs accompanied by the reflexive marker se are usually subsumed under reflexive verbs in Croatian literature and grammars (see for example Barić et al. 1997: 231), in contemporary linguistic literature they are more often considered as an instance of anticausative verbs. Schäfer (2009), for example, determines the semantic classes of verbs that can participate in the causative alternation, citing psych verbs $^{3}$ as one of these classes (Schäfer 2009: 650).
(6) Psi
plaše
Ivana.
dogs.nom.pl.
frighten.3.pl.pres. Ivan.acc.sg.
'Dogs frighten Ivan.'
(7) Ivan se
Ivan.nom.sg. se.refl.
plaši
fear.3.sg.pres.
pasa.

'Ivan fears dogs.'

\footnotetext{
3 Other semantic classes which participate in causative alternation are the change of state verbs, change of degree verbs, and non-agentive verbs of manner of motion (Schäfer 2009: 649-650).
} 
In example (7), the verb plašiti 'fear' is accompanied by the reflexive marker se and the experiencer argument is realized as a nominative subject, while the nonexperiencer (target/subject matter) argument is marked with the genitive case. It is worth noting that in the above examples the same verb plašiti means 'frighten, scare' in (6), while in (7) the verb means 'fear'. In Croatian, the non-experiencer (stimulus/subject matter/target) argument with the anticausative (reflexive) variant can vary in its morphological form. It can be expressed as the genitive, e.g. prepasti se 'be terrified, frightened', plašiti se 'fear, be afraid' (7); the dative, e.g. čuditi se 'wonder', radovati se 'rejoice', veseliti se 'rejoice', začuditi se 'astonish', razveseliti se 'cheer up, rejoice' (8); an instrumental noun phrase, e.g. očaravati se 'be enchanted', očarati se 'be enchanted, be fascinated', oduševiti se 'be delighted, be excited', oraspoložiti se 'cheer up', zabavljati se 'entertain, amuse' (9); or a prepositional phrase, e.g. živcirati se 'get nervous', ljutiti se 'be angry', brinuti se 'worry' (10):
(8) Majka
mother.nom.sg. se.refl.
čudila
wondered.past.part.
njegovim
riječima.

'Mother wondered at his words.'
(9) Ljudi
se
people.nom.pl. se.refl.

očaravaju

fascinate.3.pl.pres.

umjetnošću.

art.inst.sg.

'People are fascinated by art.'

\section{(10) Ne brinem} not worry.1.sg.pres. se.refl.

oko

sitnica.

'I don't worry about trifles.'

In some cases, the morphological marking of the non-experiencer argument can even vary with the same verb, with a slightly different meaning. The differential marking of the non-experiencer argument has been noted, for example, in the following verbs: užasavati se 'terrify', razveseliti se 'cheer up, rejoice', zaplašiti se 'scare, intimidate', zaprepastiti se 'shock'.
(11) a
$\begin{array}{lll}\text { Ivan } & \text { se } & \text { najviše } \\ \text { Ivan.nom. } & \text { se.refl. } & \text { most.adv. }\end{array}$
razveselio
bratu
'Ivan was most pleased with his brother.' 

b. Djeca
su se
razveselila
sladoledom
children.nom.pl. are. 3.pl. se.refl.
cheered.past.part.pl.neu. ice cream.inst.sg.
'The children cheered up (enjoyed) with ice cream.'

In example (11.a) the reflexive verb razveseliti se 'cheer (up)' is accompanied by two arguments - the experiencer in the nominative case, and the non-experiencer argument in the dative case, whereas in example (11.b) the same verb has the non-experiencer argument marked with the instrumental case. ${ }^{4}$

The proper characterization of thematic roles with the anticausative variant of psychological verbs depends highly on whether or not the anticausatives are considered causatives (see e.g. Chierchia 2004, Biały 2005, Schäfer 2009). If anticausatives are viewed as causative verbs (Chierchia 2004, Biały 2005), the non-experiencer argument must be labelled as a cause (or stimulus). If this view is not supported, the non-experiencer argument can be labelled as a subject matter/target (in Pesetsky's sense) or as a theme argument.

Since we have also investigated a large corpus of ObjExp verbs with regard to the possibility of having an anticausative/reflexive correlate (140 verbs), we have observed that the possibility of having an anticausative/reflexive variant strongly correlates with the semantic class of the verb. We have found that among the 140 Croatian ObjExp verbs, only 20 do not have a corresponding reflexive variant and none of these is a psychological predicate in its basic meaning (e.g. bocnuti 'prick (tease)', boljeti 'hurt', kopkati 'dig (scratch)', uhvatiti 'catch'). We conclude that all ObjExp verbs with primarily psychological meaning regularly have an anticausative/reflexive variant.

Two examples of verbs, which are not primarily psychological, but are psychological in the presented context, are given below (12-13):
(12) Neobjašnjivo
inexplicably.adv.
zapekao
jak
strong.nom.sg.
me
burned.past.part.sg.masc.
me.acc.sg.
osjećaj sramote
sense.nom.sg. shame.gen.sg.
u prsima.
'An inexplicably strong sense of shame burned in my chest.'

\footnotetext{
4 When an instrumental case is used, the verb has an agentive component in its meaning (the children have bought ice cream to cheer themselves up), whereas when the second argument is marked with a dative case this component of meaning is missing; the sentence (11.a) means simply that Ivan was happy about his brother, regardless of the cause.
} 


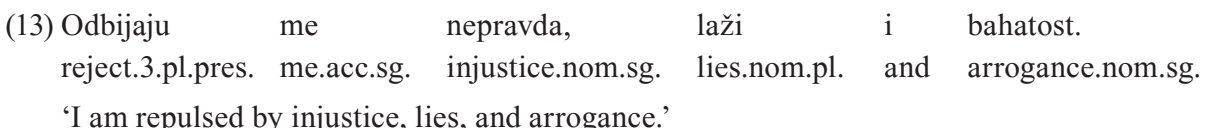

Although we have noted that the basic subject argument (non-experiencer) of an ObjExp verb is present with a reflexive verb in the form of an oblique case marked noun or prepositional phrase, Biały (2005) treats anticausative/reflexive psychological verbs as a result of argument reduction of basic ObjExp verbs, in accordance with the analysis in Reinhart (1996). In the reflexive construction, the subject argument (non-experiencer) is suppressed, which is characteristic of causative verbs according to Reinhart (1996). Therefore, for Biały (2005), the reflexivization of ObjExp verbs is proof of their causative nature. It is clear that he considers the Polish anticausative (reflexive) variant to be derived from the basic ObjExp verb. ${ }^{5}$ However, this is not a settled issue, as there is still debate on which of the variants should be considered basic. Schäfer (2009: 660) claims that "it is generally agreed on that verbs undergoing the causative alternation involve only one lexical entry and that the two variants are derivationally related", but it is far from agreed which variant should be considered basic. He adds that a third option has been suggested, according to which both versions are derived from a common source. Chierchia (2004) has proposed an analysis of anticaustive alternation based on languages that show reflexive morphology in the anticausative verb. In his analysis, anticausatives are derived from causatives through the process of reflexivization, while they also have a causative nature.

Regarding the morphological aspect of the verb, we have observed that psychological verbs can be of both aspects. Among the 40 verbs which we have investigated thoroughly, 18 are perfective, 15 imperfective, and 7 biaspectual. Only the verbs boljeti 'hurt' and zaboljeti '(start to) hurt' do not have a corresponding reflexive variant and, as expected, their primary meaning is not psychological. ${ }^{6}$ The data are presented in Table 1.

\footnotetext{
The question of why is reflexive morphology a by-product of detransitivization still seeks an answer. The same is pointed out by Schäfer (2009: 659), who says that detransitivization approaches "need to explain in what sense reflexive or non-active morphology (but not some other device) qualifies as a marker of reduction operations or unaccusative syntax".

6 In the larger corpus of 140 verbs we have compiled, 76 verbs are perfective, 57 are imperfective, and 7 are biaspectual.
} 


\section{Stativity vs. eventivity/non-stativity}

As pointed out in the introduction, various authors (Arad 1998, Pylkkänen 2000, Biały 2005, Grafmiller 2013) have claimed that ObjExp verbs can have two (stative and eventive) or three different interpretations (stative, eventive, agentive). Stative interpretation does not involve an agent and a mental change in the experiencer, e.g. brinuti 'worry', eventive interpretation involves a participant who/ which causes a mental change, but unintentionally, e.g. plašiti 'frighten, scare', and agentive reading involves an agent who "deliberately does something to bring about a mental state in the experiencer", e.g. iznenaditi 'surprise' (Arad 1998: 3). As argued by Pylkkänen (2000), stative reading involves a perception of some stimulus by the experiencer, and this perception triggers some mental state in the experiencer. The experiencer is in a specific mental state as long as he/she perceives the stimulus (or has it in mind) (Arad 1998: 4). In contrast, in the case of non-stative ObjExp verbs (eventive and agentive), stimulus precedes the mental state, and only triggers it. Arad (1998) also emphasizes that there are ObjExp verbs that have only stative reading (worry and concern), some that are hard to interpret as stative (surprise), and some that can have all three readings (frighten). Below, we will see that similar cases are true for Croatian too.

Most researchers focus either on the stativity or the agentivity of ObjExp verbs (Grafmiller 2013: 72). In this phase of our research, we will not investigate in depth whether we need to differentiate two or three groups (interpretations) of ObjExp Verbs. We will simply attempt to single out stative ObjExp verbs from non-stative ObjExp verbs. Various tests have been proposed in the literature to segregate stative from non-stative ObjExp verbs. We will apply the following tests to the group of 40 verbs: 1) the ability to form the passive; 2) the use of the verb in the punctual past; 3 ) the presence of agent-oriented adverbs; 4) the possibility for the verb to be used in the imperative mood; 5) the possibility for the verb to be a complement of a control verb. The results are shown in Table 1.

\subsection{The passive}

It has generally been assumed that the passive cannot be formed from stative verbs since they do not have external arguments (Grimshaw 1990, Bussman 
1996, Rothmayr 2009, Grafmiller 2013). We have examined the possibility for Croatian ObjExp verbs to be used in the passive in detail and have correlated this with the aspect of the verb.

Out of the 40 ObjExp verbs, 34 can form the passive, while six cannot. The ObjExp verbs that can form the passive are mostly perfective (18), to a lesser extent imperfective (9), and biaspectual (7). The ObjExp verbs which do not form the passive are almost all imperfective (čuditi 'wonder', radovati 'rejoice', veseliti 'rejoice', brinuti 'worry', boljeti 'hurt'), and only one is perfective (zaboljeti '(start to) hurt'). It is significant that the sole perfective verb which cannot be used in the passive is not primarily psychological (zaboljeti '(start to) hurt'), and it is mostly used in connection with physical pain.

The same pattern was observed in the larger corpus of 140 verbs. Out of 140 ObjExp verbs, 92 can form the passive, while 48 cannot. The ObjExp Verbs (92) which can form the passive are mostly perfective (70), and to a lesser extent imperfective (19), and only three are biaspectual. The ObjExp verbs (48) which do not form the passive are mostly imperfective (37), while very few are perfective (7), and biaspectual (4).

Sentences in the examples below present the passive use of a perfective ObjExp verb (14b), the passive use from an imperfective ObjExp verb (15b), and two examples of verbs - imperfective (16b) and perfective (17b) - which cannot be used in the passive. The active forms of the verbs are given in the examples labelled a), while the passive forms are given in the examples labelled b).

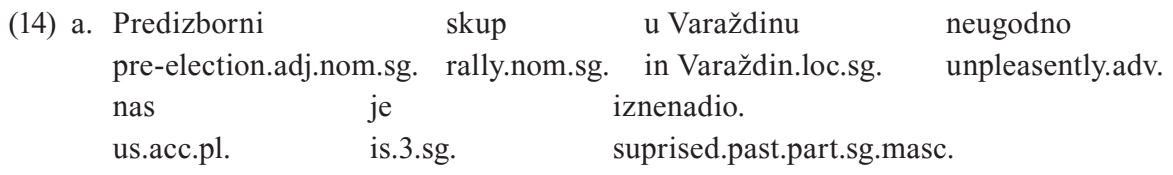

'The pre-election rally in Varaždin unpleasantly surprised us.'
b. Neugodno smo iznenađeni unpleasantly.adv. are.1.pl. surprised.pass.part.pl.masc. predizbornim skupom u Varaždinu. pre-election.adj.inst.sg rally.inst.sg. in Varaždin.loc.sg. 'We are unpleasantly surprised by the pre-election rally in Varaždin.' 
(15) a. Epidemija

globalnih

of-global.adj.gen.pl.

svijet. razmjera

epidemic.nom.sg

plaši

frightens.3.sg.pres. world.acc.sg.

'An epidemic of global proportions frightens the world.'

b. Svijet

je

world.nom.sg.

epidemijom

is. 3.sg.

globalnih

of-global.adj.gen.pl.

proportion.gen.pl.

epidemic.inst.sg.

'The world is frightened by an epidemic of global proportions.'

(16) a. Prosvjedi

sindikata protests.nom.pl union.gen.pl.

me ljute.

'The unions' protests anger me.

me.acc.sg.

anger.3.pl.pres.

b. *Ljućen sam angered.pass.part.sg.masc. am.1.sg.

prosvjedima

sindikata.

protests.inst.pl.

union.gen.pl.

'I was angered by the unions' protests.'

(17) a. Tvoja 'Your infidelity hurt me.'
b. *Zapečen
sam
burn/brown.sg.masc. am.1.sg.
tvojom
nevjerom.
your.inst.sg.
infidelity.inst.sg.

'*I am burned by your infidelity.'

\subsection{Punctual past tense}

Use of a verb in the punctual past tense requires eventive interpretation, and hence the verb is not stative (Pesetsky 1995, Grafmiller 2013). We have applied this test by adding the adverb odjednom 'at one time, all of a sudden' to sentences with ObjExp verbs. Grafmiller (2013: 91) says that "the implication is that these sentences describe a punctual change in the Experiencer, therefore they require that the predicate be interpreted as an event, and not a state."
(18) Neki
zvuk
te
odjednom
uplaši.
some.nom.sg. sound.nom.sg. you.acc.sg.
suddenly.adv.
frightens.3.sg.pres.perf.

'Some sound suddenly scares you.' 
The results show that 23 out of the 40 ObjExp verbs, which are either primarily psychological or with another primary meaning, are not attested in the punctual past. Seventeen verbs are used in the punctual past tense, which is attested in the corpora (eight perfective: iznenaditi 'surprise', ojaditi 'annoy, distress', prepasti 'terrify, frighten', razveseliti 'cheer up, rejoice', uplašiti 'scare', razočarati 'disappoint', uznemiriti 'upset', oduševiti 'delight, excite'; four biaspectual: fascinirati 'fascinate', interesirati 'interest', živcirati 'annoy', šokirati 'shock'; and five imperfective: brinuti 'worry', plašiti 'frighten, scare', zabavljati 'amuse, entertain', veseliti 'rejoice', mučiti 'torture'). Perfective verbs, which are more often passivized than imperfective verbs, are also more prone to be used in the punctual past tense. However, a larger number of verbs can be passivized (34) than can be used in the punctual past tense (23).

Grafmiller (2013) questions the validity of the punctual past test for diagnosing stativity vs. non-stativity and states that “... all Obj-Exp verb emotions have the potential to be construed as arising suddenly, though the suddenness of the onset is more likely for some emotions than others" (Grafmiller 2013: 119). He cites examples of stative verbs used with the adverb suddenly (Kramer suddenly recognized the neighborhood and found the door.) and concludes that the use of the punctual past is not a reliable test for non-stativity.

\subsection{Agent-oriented adverbs}

It is well known that the use of agent-oriented adverbs identifies the agentivity of sentences. Grafmiller (2013: 99) says that the "use of intentionally forces an interpretation of the sentence where the Agent actively does something to cause the emotion in the Experiencer." In Croatian, there are several agent-oriented adverbs that can identify the presence of an agent in a sentence (namjerno 'intentionally, deliberately', obzirno 'considerately', nevoljko 'reluctantly', tajno 'secretly', etc.). For the time being, we have attempted to add only the adverb namjerno 'intentionally, deliberately' to the 40 designated verbs. Our research has shown that 16 of the investigated verbs can be accompanied by the agent-oriented adverb namjerno 'intentionally, deliberately'. One of the examples found by a corpus search is given in (19): 


$\begin{array}{lllll}\text { Zašto } & \text { muškarci } & \text { namjerno } & \text { ljute } & \text { žene? } \\ \text { why } & \text { men.nom.pl. } & \text { deliberately.adv. } & \text { anger.3.pl.pres. } & \text { women.acc.pl. }\end{array}$

'Why do men deliberately anger women?'

Seven of the verbs found with agent-oriented adverbs are imperfective (hrabriti 'encourage', ljutiti 'anger', plašiti 'frighten, scare', srditi 'anger', zabavljati 'amuse, entertain', mučiti 'torture', uzrujavati 'upset'), six are perfective (iznenaditi 'surprise', ojaditi 'annoy, distress', prepasti 'terrify, frighten', uplašiti 'scare', uzrujati 'upset', razočarati 'disappoint') and three are biaspectual (živcirati 'annoy', frustrirati 'frustrate', šokirati 'shock'). More imperfective verbs pass this test than perfective ones, but the difference between the two aspect classes is only one verb.

\subsection{Imperative mood}

The use of a verb in the imperative mood also indicates the agentivity or eventivity of a verb, and stative verbs cannot be used in the imperative mood (Bussman 1996, Biały 2005, Grafmiller 2013). Although we have not found evidence in the corpus for the imperative use of all the researched verbs, according to the speaker's intuitions, all verbs except for the verbs boljeti 'hurt' and zaboljeti '(start to) hurt' can be used in the imperative context. These verbs are not primarily psychological. An example is given in (20).

(20)

$\begin{array}{lll}\text { Iznenadi } & \text { ga } & \text { konačno! } \\ \text { surprise.2.sg.imp. } & \text { him.acc.sg. } & \text { finally.adv. } \\ \text { 'Surprise him finally!' } & & \end{array}$

\subsection{Complements to control verbs}

Grafmiller (2013) cites embedding under control verbs as one of the diagnostics for agentivity. The implicit subject of the complement clause (infinitival) must be interpreted as volitional, and therefore the acceptability of a verb in such clauses can be taken as evidence that the verb allows an agentive subject (Grafmiller 2013: 227). We attempted to embed the 40 ObjExp verbs in sentences that have the verb natjerati 'make, compel' as the main predicate. This is an object control 
verb (Natjerao sam ga pisati zadaću. 'I made him write (do) a homework.'). We did not find any of these verbs embedded under the control verb natjerati 'make, compel'.

However, results differ when we attempted to embed these verbs under the subject control verb odlučiti 'decide'. This test showed that 32 ObjExp verbs can be complements of a subject control verb and it is impossible to embed only eight as complements to the verb odluciti 'decide'. These verbs are boljeti 'hurt', brinuti 'worry', čuditi 'wonder' interesirati 'interest', srditi 'anger', uzrujavati 'upset', zaboljeti '(start to) hurt' and zabrinuti 'worry, make worried'. For two verbs, it is difficult to decide by the speaker's intuition if they can be a complement of the subject control verb (these are the verbs veseliti 'rejoice' and frustrirati 'frustrate'). The result of this test indicates once again that the perfective verbs are more prone to be interpreted as eventive. Indeed, five of eight verbs that do not pass this test are imperfective, one is biaspectual, and two are perfective.

In (21) there is an example of an imperfective verb, which can be construed as a complement of the subject control verb odlučiti 'to decide':

$\begin{array}{lllll}\text { (21) Odlučila } & \text { je } & \text { razveseliti } & \text { svoje } & \text { slušatelje. } \\ \text { decide.past.part.sg.fem. } & \text { is.3.sg. } & \text { cheer up.inf. } & \text { her.acc.sg. } & \text { listeners.acc.pl. }\end{array}$

'She decided to cheer up her listeners.'

\section{Conclusion}

We have found that 10 of the 40 examined verbs pass all diagnostics for nonstativity (eventivity or/and agentivity), i.e. they are reflexivized by the marker se, can be passivized, are used in the punctual past tense, are combined with agent-oriented adverbs, can be used in the imperative mood, and can be embedded under subject control verbs. These are the verbs iznenaditi 'surprise', mučiti 'torture', ojaditi 'annoy, distress', plašiti 'frighten, scare', prepasti 'terrify, frighten', razočarati 'disappoint', šokirati 'shock', uplašiti 'scare', zabavljati 'amuse, entertain', and živcirati 'annoy'. Five of these verbs are perfective, three are imperfective, and two are biaspectual. 
Only two verbs of all the 40 verbs fail to pass any test for non-stativity (eventivity or agentivity) - the imperfective verb boljeti 'hurt' and its perfective variant zaboljeti '(start to) hurt', whose primary meanings are not psychological. These verbs also do not have a reflexive variant. As we have noted earlier, it seems that all ObjExp verbs with primarily psychological meaning can have a reflexive (anticaustive) variant.

If we put aside the possibility of building the anticausative/reflexive variant (which is possible for all verbs except for non-primary psychological verbs), there is only one verb that is positive only to one non-stativity (eventivity or agentivity) diagnostics. The verb čuditi 'wonder' passes only the imperative test. Three verbs pass only two tests for non-stativity in addition to the imperative test - the verb brinuti 'worry' passes the punctual past test, the verb srditi 'anger' can be composed with agent-oriented adverbs, and zabrinuti 'worry, make worried' passes the passive test. These facts give us some picture of the behaviour of Croatian ObjExp verbs with respect to stativity/non-stativity. At one end, there are ten verbs that can clearly be interpreted as non-stative, and, at the other end, there are six verbs which are difficult to interpret as non-stative. The rest of the verbs, amounting to 24 , are likely to be interpreted as non-stative as they pass some tests for non-stativity. Hence, most verbs (34) can have a non-stative interpretation. The overall impression so far is that the number of Croatian ObjExp verbs that can be interpreted as non-stative (eventive or agentive) is larger than the number of verbs that cannot. There are also some Croatian ObjExp verbs which are mostly not interpreted as stative (e.g. iznenaditi 'surprise', razljutiti 'anger') since their meaning refers to one point in time (iznenaditi 'surprise') or to the beginning of a state (razljutiti 'anger'). The same has also been noted by Arad (1998: 6).

If we compare the relation of a single test to the aspect of the verb, we will see that more perfective verbs passivize, are used in the punctual past tense, and can be complements of subject control verbs. Almost all the verbs are used in the imperative mood, except for ObjExp verbs with non-basic psychological meaning, so the imperative test is not really valid. On the other hand, there is a greater number of imperfective verbs used with agent-oriented adverbs, but the difference is only one verb. If we do not take into account the use of the verb in 
the punctual past, which, according to Grafmiller (2013), is not a reliable test for non-stativity, we still have more tests passed by perfective verbs (3).

Finally, although our data do not give a completely unambiguous picture and our results have to be taken with great caution since stative/non-stative diagnostics were applied to a small set of verbs, some conclusions can be made:

1. All Croatian primary psychological verbs have an anticausative (reflexive) variant.

2. Most Croatian ObjExp verbs have a stative and non-stative reading (agentive and/or eventive).

3. Perfective verbs are probably more prone to be interpreted as events. ${ }^{7}$

A more detailed consideration and validation of tests proposed in the literature and the inclusion of a larger number of verbs in the research would give a better picture of the aspectual nature of Croatian ObjExp verbs. Therefore, more thorough research is needed on Croatian ObjExp Verbs and special attention must be paid to the relation between ObjExp verbs and their anticausative variant with respect to the direction of derivation.

Table 1. The results of diagnostics tests

\begin{tabular}{|l|l|l|l|l|l|l|l|l|}
\hline \multicolumn{2}{|l|}{} & \multicolumn{5}{l|}{ NON-STATIVE DIAGNOSTICS } \\
\hline VERB & $\begin{array}{l}\text { Primarily } \\
\text { psych. } \\
\text { meaning }\end{array}$ & $\begin{array}{l}\text { Reflexive } \\
\text { marker se }\end{array}$ & Aspect & Passive & $\begin{array}{l}\text { Punctual } \\
\text { Past } \\
\text { Tense }\end{array}$ & $\begin{array}{l}\text { Agent- } \\
\text { oriented } \\
\text { Adverb }\end{array}$ & Imperative & $\begin{array}{l}\text { Subject } \\
\text { Control }\end{array}$ \\
\hline $\begin{array}{l}\text { boljeti } \\
\text { 'hurt' }\end{array}$ & no & no & impf. & no & no & no & no & no \\
\hline
\end{tabular}

\footnotetext{
7 One of the reviewers has pointed to us a very interesting fact. The passivized variant of the ObjExp verb plašiti 'frighten, scare' (example 15b) has clearly an agentive interpretation (Svijet je plašen epidemijom globalnih razmjera. 'The world is frightened by an epidemic of global proportions.'). When the perfective variant of the verb plašiti 'frighten, scare' (uplašiti 'to get scared') is used in the same passivized sentence, the sentence has non-agentive interpretation (Svijet je uplašen epidemijom globalnih razmjera. 'The world has got scared by an epidemic of global proportions.'). The interpretation of passivized sentences (the one with imperfective verb being agentive, and the one with perfective verb being non-agentive) is opposite of what we have claimed for interpretation of anticausative sentences (the ones with perfective verb being prone to non-stative, eventive interpretation and the ones with imperfective verbs to stative interpretation). Although we do not have an answer to that question right now, that observation has to be taken into consideration since it directs us to look at the bigger picture, not just at anticausatives.
} 


\begin{tabular}{|c|c|c|c|c|c|c|c|c|}
\hline $\begin{array}{l}\text { brinuti } \\
\text { 'worry' }\end{array}$ & yes & yes & impf. & no & yes & no & yes & no \\
\hline $\begin{array}{l}\text { čuditi } \\
\text { 'wonder' }\end{array}$ & yes & yes & impf. & no & no & no & yes & no \\
\hline $\begin{array}{l}\text { deprimirati } \\
\text { 'depress' }\end{array}$ & yes & yes & biasp. & yes & no & no & yes & yes \\
\hline $\begin{array}{l}\text { fascinirati } \\
\text { 'fascinate' }\end{array}$ & yes & yes & biasp. & yes & yes & no & yes & yes \\
\hline $\begin{array}{l}\text { frustrirati } \\
\text { 'frustrate' }\end{array}$ & yes & yes & biasp. & yes & no & yes & yes & no/yes \\
\hline $\begin{array}{l}\text { hrabriti } \\
\text { 'encourage' }\end{array}$ & yes & yes & impf. & yes & no & yes & yes & yes \\
\hline $\begin{array}{l}\text { inspirirati } \\
\text { 'inspire' }\end{array}$ & yes & yes & biasp. & yes & no & no & yes & yes \\
\hline $\begin{array}{l}\text { interesirati } \\
\text { 'interest' }\end{array}$ & yes & yes & biasp. & yes & yes & no & yes & no \\
\hline $\begin{array}{l}\text { isprepadati } \\
\text { 'frighten' }\end{array}$ & yes & yes & perf. & yes & no & no & yes & yes \\
\hline $\begin{array}{l}\text { izmučiti } \\
\text { 'torture' }\end{array}$ & yes & yes & perf. & yes & no & no & yes & yes \\
\hline $\begin{array}{l}\text { iznenaditi } \\
\text { 'surprise' }\end{array}$ & yes & yes & perf. & yes & yes & yes & yes & yes \\
\hline $\begin{array}{l}\text { ljutiti } \\
\text { 'anger' }\end{array}$ & yes & yes & impf. & yes & no & yes & yes & yes \\
\hline $\begin{array}{l}\text { mučiti } \\
\text { 'torture' }\end{array}$ & yes & yes & impf. & yes & yes & yes & yes & yes \\
\hline $\begin{array}{l}\text { očarati } \\
\text { 'enchant, } \\
\text { fascinate' }\end{array}$ & yes & yes & perf. & yes & no & no & yes & yes \\
\hline $\begin{array}{l}\text { očaravati } \\
\text { 'enchant' }\end{array}$ & yes & yes & impf. & yes & no & no & yes & yes \\
\hline $\begin{array}{l}\text { oduševiti } \\
\text { 'delight, } \\
\text { excite' }\end{array}$ & yes & yes & perf. & yes & yes & no & yes & yes \\
\hline $\begin{array}{l}\text { ohrabriti } \\
\text { 'encourage' }\end{array}$ & yes & yes & perf. & yes & no & no & yes & yes \\
\hline $\begin{array}{l}\text { ojaditi } \\
\text { 'annoy, } \\
\text { distress' }\end{array}$ & yes & yes & perf. & yes & yes & yes & yes & yes \\
\hline $\begin{array}{l}\text { oraspoložiti } \\
\text { 'cheer up' }\end{array}$ & yes & yes & perf. & yes & no & no & yes & yes \\
\hline $\begin{array}{l}\text { plašiti } \\
\text { 'frighten, } \\
\text { scare' }\end{array}$ & yes & yes & impf. & yes & yes & yes & yes & yes \\
\hline $\begin{array}{l}\text { prepadati } \\
\text { 'frighten' }\end{array}$ & yes & & impf. & yes & no & no & yes & yes \\
\hline $\begin{array}{l}\text { prepasti } \\
\text { 'terrify, } \\
\text { frighten' }\end{array}$ & yes & yes & perf. & yes & yes & yes & yes & yes \\
\hline
\end{tabular}




\begin{tabular}{|c|c|c|c|c|c|c|c|c|}
\hline $\begin{array}{l}\text { radovati } \\
\text { 'rejoice' }\end{array}$ & yes & yes & impf. & no & no & no & yes & yes \\
\hline $\begin{array}{l}\text { razljutiti } \\
\text { 'anger' }\end{array}$ & yes & yes & perf. & yes & no & no & yes & yes \\
\hline $\begin{array}{l}\text { razočarati } \\
\text { 'disappoint' }\end{array}$ & yes & yes & perf. & yes & yes & yes & yes & yes \\
\hline $\begin{array}{l}\text { razveseliti } \\
\text { 'cheer up, } \\
\text { rejoice' }\end{array}$ & yes & yes & perf. & yes & yes & no & yes & yes \\
\hline $\begin{array}{l}\text { srditi } \\
\text { 'anger' }\end{array}$ & yes & yes & impf. & no & no & yes & yes & no \\
\hline $\begin{array}{l}\text { šokirati } \\
\text { 'shock' }\end{array}$ & yes & yes & biasp. & yes & yes & yes & yes & yes \\
\hline $\begin{array}{l}\text { uplašiti } \\
\text { 'scare' }\end{array}$ & yes & yes & perf. & yes & yes & yes & yes & yes \\
\hline $\begin{array}{l}\text { uznemiriti } \\
\text { 'upset' }\end{array}$ & yes & yes & perf. & yes & yes & no & yes & yes \\
\hline $\begin{array}{l}\text { uzrujati } \\
\text { 'upset' }\end{array}$ & yes & yes & perf. & yes & no & yes & yes & no \\
\hline $\begin{array}{l}\text { uzrujavati } \\
\text { 'upset' }\end{array}$ & yes & yes & impf. & yes & no & yes & yes & no \\
\hline $\begin{array}{l}\text { veseliti } \\
\text { 'rejoice' }\end{array}$ & yes & yes & impf. & no & yes & no & yes & no/yes \\
\hline $\begin{array}{l}\text { zabavljati } \\
\text { 'amuse, } \\
\text { entertain' }\end{array}$ & yes & yes & impf. & yes & yes & yes & yes & yes \\
\hline $\begin{array}{l}\text { zaboljeti } \\
\text { '(start to) } \\
\text { hurt' }\end{array}$ & no & no & perf. & no & no & no & no & no \\
\hline $\begin{array}{l}\text { zabrinuti } \\
\text { 'worry, } \\
\text { make } \\
\text { worried' }\end{array}$ & yes & yes & perf. & yes & no & no & yes & no \\
\hline $\begin{array}{l}\text { začuditi } \\
\text { 'astonish' }\end{array}$ & yes & yes & perf. & yes & no & no & yes & yes \\
\hline $\begin{array}{l}\text { zaplašiti } \\
\text { 'frighten' }\end{array}$ & yes & yes & perf. & yes & no & no & yes & yes \\
\hline $\begin{array}{l}\text { živcirati } \\
\text { 'annoy' }\end{array}$ & yes & yes & biasp. & yes & yes & yes & yes & yes \\
\hline
\end{tabular}

\section{References}

Alexiadou, Artemis; Gianina Iordăchioaia. 2014. The psych causative alternation. Lingua 148. 53-79. https://www.academia.edu/11844275/The_Psych_Causative_Alternation (accessed 15 February 2019).

Arad, Maya. 1988. Psych-notes. UCL Working Papers in Linguistics 10. 1-22. 
BARIĆ, EugeniJa et al. ${ }^{2}$ 1997. Hrvatska gramatika. Školska knjiga. Zagreb.

Belletti Adriana; Rizzi, Luigi. 1988. Psych-verbs and $\theta$ theory. Natural Language and Linguistic Theory 6. 291-352.

BiaŁy, Adam. 2005. Polish Psychological Verbs at the Lexicon-Syntax Interface in Cross-linguistic Perspective. Frankfurt am Main. Peter Lang.

Birtić, Matea; Runjaić, Siniša. 2019. Sintaktičko-semantička podjela psiholoških glagola u hrvatskome jeziku. Filologija 73. 1-25. dx.doi.org/10.21857/mjrl3ux709.

BiRTić, MateA et al. 2012. Školski rječnik hrvatskoga jezika. Institut za hrvatski jezik i jezikoslovlje - Š Skolska knjiga. Zagreb.

BRAČ, IvanA. 2018. Instrumental u hrvatskom jeziku. Institut za hrvatski jezik i jezikoslovlje. Zagreb.

Brač, IVANA; MATAS IVANKOVIĆ, IVANA. 2018. Психологические глаголы в хорватском и русском языках. Research of Verbal Valency in Slavic Languages in the Past and Present. Výzkum slovesné valence ve slovanských zemích včera a dnes. Eds. Skwarska, Karolína; Kaczmarska, Elżbieta. Slovanský ústav AV ČR. Praha. v.v.i., 351-369. [BRAČ, Ivana; Matas Ivanković, Ivana. 2018. Psihologičeskie glagoly v horvatskom i russkom jazykah. Research of Verbal Valency in Slavic Languages in the Past and Present. Výzkum slovesné valence ve slovanských zemich včera a dnes. Eds. Skwarska, Karolína; Kaczmarska, Elżbieta. Slovanský ústav AV ČR. Praha. v.v.i., 351-369.]

Bussman, Hadumod. 1996. Routledge Dictionary of Language and Linguistics. Routledge. London - New York.

Chierchia, Gennaro. 2004. A Semantics for Unaccusatives and its Syntactic Consequences. The unaccusativity puzzle: Explorations of the syntax-lexicon interface. Ed. Alexiadou, Artemis; Anagnostopoulou, Elena; Everaert, Martin. Oxford University Press. Oxford - New York.

Croft, William. 1993. Case marking and the semantics of mental verbs. Semantics and Lexicon. Ed. Pustejovsky, James. Kluwer Academic Publisher. 55-77.

Grafmiller, JASON. 2013. The semantics and syntactic choice. An analysis of English emotion verbs. Ph.D. dissertation. Stanford University. Stanford, CA.

Grimshaw, Jane. 1990. Argument Structure. MIT Press. Cambridge.

Landau, Idan. 2010. The Locative Syntax of Experiencers. MIT Press. Cambridge.

Pesetsky, David. 1995. Zero syntax: Experiencers and cascades. MIT Press. Cambridge.

PylkKänen, Lina. 2000. On Stativity and Causation. Events as Grammatical Objects. Eds. Tenny, Carol; Pustejovsky, James. CSLI Publications. Stanford.

ReInhart, TANyA. 1996. Syntactic realization of verbal concepts: reflexives and unaccusatives. https://staticweb.hum.uu.nl/uilots/Tanya.Reinhart/personal/Papers/pdf/ Lexic_96.pdf (accessed 23 February 2021). 
Rothmayr, Antonia. 2009. The Structure of Stative Verbs. John Benjamins Publishing Company. Amsterdam - Philadelphia. doi.org/10.1075/la.143.

Rozwadowska, Bożena. 2017. Psychological Verbs and Psychological Adjectives. https://pracownik.kul.pl/files/10932/public/syncom_psych_verbs_revised. pdf?1461263014580. (accessed 15 January 2019).

SCHÄFER, FloriAn. 2009. The causative alternation. Language and Linguistics Compass 3/2. 641-681. doi.org/10.1111/j.1749-818X.2009.00127.x.

ŠARAVANJA, LidiJa. 2011. Argumentna struktura psiholoških glagola u hrvatskom jeziku. Suvremena lingvistika 37. 241-257.

Šonje, Jure (Ed.). 2000. Rječnik hrvatskoga jezika. Leksikografski zavod Miroslav Krleža - Školska knjiga. Zagreb.

\section{Osnovne značajke i aspektna svojstva glagola s objektnim iskustvenikom u hrvatskom jeziku}

\section{Sažetak}

U radu se opisuju temeljne značajke hrvatskih glagola s objektnim iskustvenikom (tematske uloge, argumentna struktura, antikauzativna inačica, glagolski vid). Posebna je pozornost dana aspektnim svojstvima tih glagola u hrvatskome jeziku. Mnogi autori (Arad 1998, Pylkkänen 2000, Biały 2005, Grafmiller 2013) ističu da glagoli s objektnim iskustvenikom nisu jedinstvena aspektna skupina glagola s obzirom na to da se mogu interpretirati kao stativni i ne-stativni (tj. događajni i/ili agentivni) glagoli. Na korpus od četrdeset glagola s objektnim iskustvenikom primijenjeno je pet testova koji se upotrebljavaju za razlikovanje stativne i ne-stativne interpretacije glagola: upotreba pasiva, upotreba u trenutačnoj prošlosti (engl. punctual past tense), supojavljivanje s agentivnim prilozima, upotreba u imperativnome načinu te pojava glagola kao dopune nadzornomu glagolu (Grafmiller 2013). Rezultati ovoga istraživanja pokazali su da svi hrvatski glagoli s objektnim iskustvenikom i primarno psihološkim značenjem imaju antikauzativnu inačicu tvorenu povratnom česticom se, da većina hrvatskih glagola $\mathrm{s}$ objektnim iskustvenikom ima dvije (ili tri) interpretacije (stativnu i ne-stativnu) te da su perfektivni glagoli, vrlo vjerojatno, skloniji ne-stativnoj interpretaciji.

Keywords: Psychological Verbs, Object Experiencer Verbs, Aspectual properties, Anticausative verbs, Croatian

Ključne riječi: psihološki glagoli, glagoli s objektnim iskustvenikom, aspektna svojstva, antikauzativni glagoli, hrvatski jezik 